\title{
Nitrile-Containing Phenolic Glucosides from the Leaves of Glochidion acuminatum
}

\author{
Yukiko Yamashita-Higuchi, ${ }^{a}$ Sachiko Sugimoto, ${ }^{a}$ Katsuyoshi Matsunami, ${ }^{a}$ Masanori Inagaki,${ }^{b}$ \\ Hideaki Otsuka, ${ }^{*, a, b}$ and Yoshio Takeda ${ }^{b}$ \\ ${ }^{a}$ Graduate School of Biomedical and Health Sciences, Hiroshima University; 1-2-3 Kasumi, Minami-ku, Hiroshima \\ 734-8553, Japan: and ${ }^{b}$ Faculty of Pharmacy, Yasuda Women's University; 6-13-1 Yasuhigashi, Asaminami-ku, \\ Hiroshima 731-0153, Japan.
}

Received September 5, 2014; accepted October 19, 2014

From the EtOAc-soluble fraction of a MeOH extract of the leaves of Glochidion acuminatum, six new compounds along with five known ones were isolated. The structures of the new compounds were elucidated to be two gallates, a $p$-hydroxybenzoate and an $(S)$-2-(4-hydroxycyclohex-1-en-1-yl)acetate of a nitrile-containing phenolic glucoside, methyl 2-(2-hydroxyphenyl)acetate $\beta$-D-glucopyranoside, and $(S)$-methyl 2-[4-sulfooxycyclohex-1-en-1-yl]acetate on the basis of spectroscopic evidence.

Key words Glochidion acuminatum; Euphorbiaceae; 2-(2,4-dihydroxyphenyl)acetonitrile; gallate; sulfate

In previous works, a novel dimeric butenolide ${ }^{1)}$ and $\mathrm{C}-8$ compounds ${ }^{2}$ were isolated from the $1-\mathrm{BuOH}$-soluble fraction of a methanol $(\mathrm{MeOH})$ extract of leaves of Glochidion acuminatum Müller-Argoviensis. It is known that the larvae of the Epicephala moth feed on the fruit of G. acuminatum. ${ }^{3)}$ From the EtOAc-soluble fraction of a $\mathrm{MeOH}$ extract of the leaves of $G$. acuminatum, two gallic acid $(\mathbf{1}, \mathbf{2})$, one $p$-hydroxybenzoic acid (3), and one (S)-1-(4-hydroxycyclohex-1-en-1-yl)acetic acid ester (4) of a nitrile-containing phenolic glucoside, a methyl 2-(2-hydroxyphenyl)acetate $\beta$-D-glucopyranoside (5), and a $(S)$-methyl 2-[4-sulfooxycyclohex-1-en-1-yl]acetate (6), along with five known compounds, $(+)$-menisdaurilide (7), $(+)$-aquilegiolide $(\mathbf{8}),{ }^{4)}(-)$-loliolide $(9),{ }^{5)}(+)$-epigallocatechin 3- $O$-gallate (10), ${ }^{6}$ and phloretin $4^{\prime}-O-\beta$-D-glucopyranoside (11) ${ }^{7)}$ were isolated (Fig. 1).

Compounds 1-6 were isolated using various separation methods, i.e. normal and reversed-phase silica gel column chromatography, HPLC and droplet counter-current chromatography. The structures of the new compounds were elucidated on the basis of spectroscopic evidence and those of the known compounds were identified by comparison with reported spectral data in the literature.

Compound 1, $[\alpha]_{\mathrm{D}}-45.1$, was isolated as an amorphous powder and its elemental composition was determined to be $\mathrm{C}_{21} \mathrm{H}_{21} \mathrm{NO}_{11}$ by observation of a quasi-molecular ion peak in high-resolution (HR) electrospray-ionization (ESI) MS. The IR spectrum exhibited absorptions due to hydroxy groups $\left(3323 \mathrm{~cm}^{-1}\right)$, a triple bond $\left(2260 \mathrm{~cm}^{-1}\right)$, an ester carbonyl group $\left(1699 \mathrm{~cm}^{-1}\right)$, an aromatic ring $\left(1614\right.$ and $\left.1511 \mathrm{~cm}^{-1}\right)$, and phenolic and aliphatic $\mathrm{C}-\mathrm{O}$ bonds $\left(1239\right.$ and $\left.1073 \mathrm{~cm}^{-1}\right)$, respectively, and the presence of the aromatic ring was also supported by the UV absorption band at $278 \mathrm{~nm}$. The ${ }^{1} \mathrm{H}-\mathrm{NMR}$ spectral data comprised three aromatic protons $\left[\delta_{\mathrm{H}} 6.51(\mathrm{dd}\right.$, $J=8,2 \mathrm{~Hz}), 6.69(\mathrm{~d}, J=2 \mathrm{~Hz})$ and $7.12(\mathrm{~d}, J=8 \mathrm{~Hz})]$, coupled in an ABX system, one singlet aromatic signal for two protons $\left(\delta_{\mathrm{H}} 7.08\right)$, isolated methylene protons $\left[\delta_{\mathrm{H}} 3.77(\mathrm{~d}, J=11 \mathrm{~Hz})\right.$ and $3.78(\mathrm{~d}, J=11 \mathrm{~Hz})]$ and an anomeric proton $\left[\delta_{\mathrm{H}} 4.87(\mathrm{~d}\right.$, $J=7 \mathrm{~Hz})]$. The ${ }^{13} \mathrm{C}-\mathrm{NMR}$ spectrum exhibited five typical signals $\left[\delta_{\mathrm{C}} 110.4 \times 2(\mathrm{~d}), 121.4\right.$ (s), 139.9 (s), $146.5 \times 2$ (s), and 168.4 (s)] assignable to a gallic acid moiety (Table 1), and acid hydrolysis of 1 liberated D-glucose as a sugar component. Of the remaining eight carbon signals, $\delta_{\mathrm{C}} 120.1$ (s) was assigned as that of a nitrile functional group with a typical IR absorption band at $2260 \mathrm{~cm}^{-1}$, and six $s p^{2}$ signals as those of a trisubstituted benzene ring (Table 1). The heteronuclear multiple bond correlation (HMBC) spectroscopy (Fig. 2) between methylene protons $\left(\delta_{\mathrm{H}} 3.77\right.$ and 3.78$)$ and the nitrile carbon, C-2 and C-6 [with $\delta_{\mathrm{H}} 7.12(\mathrm{~d}, J=8 \mathrm{~Hz})$ ], $\mathrm{H}-5$ and $\mathrm{C}-1$ and 3, and H-6 and $\mathrm{C}-2$ and 4 , established the structure of the aglycone to be as shown in Fig. 1. This substitution arrangement is rarely found in nature. Further correlations, the anomeric proton with $\mathrm{C}-2$ and $\mathrm{H}_{2}-6^{\prime}$ with the carbonyl carbon of the galloyl moiety, were also observed in the HMBC spectrum (Fig. 2). Mild alkaline hydrolysis of $\mathbf{1}$ with $\mathrm{NaOCH}_{3}$ in $\mathrm{MeOH}$ gave a deacylated derivative, 2-(2,4-dihydroxyphenyl)acetonitrile 2- $O-\beta$-Dglucopyranoside (1a) (=12 in Fig. 1). Therefore, the structure of 1 was elucidated to be 2-(2,4-dihydroxyphenyl)acetonitrile $2-O-\beta$-D-glucopyranoside $6^{\prime}-O$-gallate, as shown in Fig. 1. 2-(2,4-Dihydroxyphenyl)acetonitrile $2-O-\beta$-D-glucopyranoside $(\mathbf{1 a}=\mathbf{1 2})$ was first isolated in 1994 from Ehretia philippinensis, as ehretioside $\left.\mathrm{B},{ }^{8}\right)$ while in $2005, \mathrm{Su}$ et al. claimed the first isolation of $\mathbf{1 2}$ from the roots of Semiaquilegia adoxoides (Ranunculaceae) as a novel cyanogenic glucoside.9) However, compound 12, isolated by Su et al. is ehretioside B (1a) and it is not cyanogenic.

Compound 2, $[\alpha]_{\mathrm{D}}-5.12$, was isolated as an amorphous powder and its elemental composition was determined to be $\mathrm{C}_{28} \mathrm{H}_{25} \mathrm{NO}_{15}$ by HR-ESI-MS. The IR and UV spectra were similar to those of $\mathbf{1}$, and the NMR spectra also showed close resemblance with those of 1 . In the ${ }^{1} \mathrm{H}-\mathrm{NMR}$ spectrum, two two-proton singlet signals $\left(\delta_{\mathrm{H}} 7.10\right.$ and 7.17) were observed in the aromatic region and five sets of signals assignable to a gallic acid moiety were observed in the ${ }^{13} \mathrm{C}-\mathrm{NMR}$ spectrum. The elemental composition of $\mathbf{2}$ coincided with the presence of one more galloyl unit in $\mathbf{2}$ than in 1. In the NMR spectra, H-3' was obviously shifted downfield $\left(\delta_{\mathrm{H}} 5.26\right)$, and C-3' shifted downfield by $1.0 \mathrm{ppm}$, and both $\mathrm{C}-2^{\prime}$ and $\mathrm{C}-4^{\prime}$ shifted upfield by $1.5 \mathrm{ppm}$ (Table 1 ), when these signals were compared with 


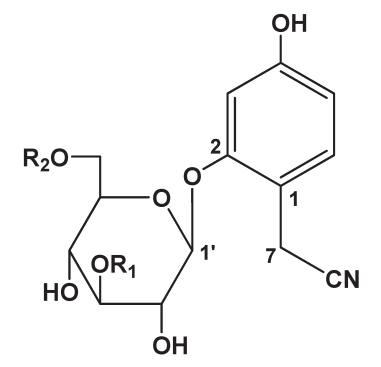

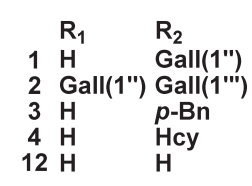<smiles>COc1ccccc1CC(=O)O</smiles>

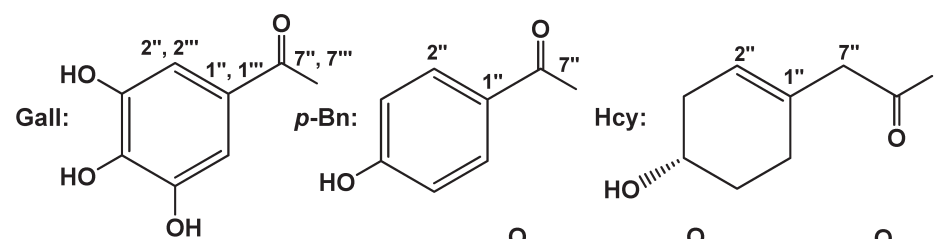<smiles>CC(=O)CC1=CC[C@H](O)CC1</smiles><smiles>O=C1C=C2C=C[C@@H](O)C[C@H]2O1</smiles><smiles>O=C1C=C2C=C[C@H](O)C[C@H]2O1</smiles><smiles>CC1(C)C[C@H](O)C[C@@]2(C)OC(=O)C=C12</smiles><smiles>O=C(Oc1cc(O)c(C(=O)CCc2ccc(O)cc2)c(OC(=O)[C@@H]2Cc3c(O)cc(O)cc3O[C@H]2c2cc(O)c(O)c(O)c2)c1)c1cc(O)c(O)c(O)c1</smiles>

Fig. 1. Structures of Compounds Isolated

those of 1. In the HMBC spectrum, H-3' showed a significant correlation peak with one of the carbonyl groups in the galloyl moiety and a $\mathrm{H}-1^{\prime}-\mathrm{H}-2^{\prime}-\mathrm{H}-3^{\prime}-\mathrm{H}$ contiguous relation was observed on ${ }^{1} \mathrm{H}-{ }^{1} \mathrm{H}$ correlation spectroscopy. Therefore, the structure of $\mathbf{2}$ was elucidated to be 2-(2,4-dihydroxyphenyl)acetonitrile $2-O-\beta$-D-glucopyranoside $\quad 3^{\prime}, 6^{\prime}$-O-digallate, as shown in Fig. 1.

Compound 3, $[\alpha]_{\mathrm{D}}-42.9$, was isolated as an amorphous powder and it elemental composition was determined to be $\mathrm{C}_{21} \mathrm{H}_{21} \mathrm{NO}_{9}$. Its IR spectrum also exhibited a characteristic absorption for a triple bond and its NMR spectra were similar to those of compound $\mathbf{1}$. Since the aromatic proton signals of the acyl substituent appeared as AB doublets, $7.90(2 \mathrm{H}$, $\mathrm{d}, J=9 \mathrm{~Hz}, \mathrm{H}-2^{\prime \prime}$ and $\left.6^{\prime \prime}\right)$ and $6.82\left(2 \mathrm{H}, \mathrm{d}, J=9 \mathrm{~Hz}, \mathrm{H}-2^{\prime \prime}\right.$ and $\left.5^{\prime \prime}\right)$, together with the presence of a highly deshielded carbon signal at $\delta_{\mathrm{C}}$ 163.6, the galloyl group in 1 must be replaced by $p$-hydroxybenzoate. Therefore, the structure of $\mathbf{3}$ was elucidated to be 2-(2,4-dihydroxyphenyl)acetonitrile $2-O-\beta$-Dglucopyranoside 6'-O-p-hydroxybezoate, as shown in Fig. 1.

Compound $4,[\alpha]_{\mathrm{D}}-61.8$, was isolated as an amorphous powder and its elemental composition was $\mathrm{C}_{22} \mathrm{H}_{27} \mathrm{NO}_{9}$. Spectroscopic evidence revealed that compound $\mathbf{4}$ was a similar compound to $\mathbf{1}-\mathbf{3}$, the acyl substituent being different. As revealed by the NMR spectroscopic data, the acyl moiety comprised one trisubstituted double bond, and four methylenes, one oxygenated methine carbon and a carbonyl carbon. Judging from this elemental composition, one degree of unsaturation must be satisfied by the formation of a ring system in the acyl framework. The above evidence substantiates that the structure of the acyl group was 2-(4-hydroxycyclohex-1-en-1yl)acetate, which is found as an acyl moiety in various compounds, isolated from the 1-BuOH-soluble fraction of the same $\mathrm{MeOH}$ extract of the title plant. ${ }^{2)}$ Since the absolute configuration at the 4-position of the methyl 2-(4-hydroxycyclohex-1en-1-yl)acetate, isolated as an alkaline hydrolysis product from glochidacuminoside B, which was obtained from the same plant ${ }^{2}{ }^{2}$ was determined by the modified Mosher's method, it must have the same $S$ configuration. Therefore, the structure of 4 was elucidated to be 2-(2,4-dihydroxyphenyl)acetonitrile 2- $O-\beta$-D-glucopyranoside 6 '- $O-(S)$-2-(4-hydroxycyclohex-1-en1-yl)acetate, as shown in Fig. 1.

Compound 5, $[\alpha]_{\mathrm{D}}-38.0$, was isolated as an amorphous powder and its elemental composition was determined to be $\mathrm{C}_{15} \mathrm{H}_{20} \mathrm{O}_{8}$. In the ${ }^{13} \mathrm{C}-\mathrm{NMR}$ spectrum, six typical signals were 
Table 1. ${ }^{13} \mathrm{C}-\mathrm{NMR}$ Spectra Data for Compounds $\mathbf{1}-\mathbf{5}$ and $\mathbf{1 a}\left(100 \mathrm{MHz}, \mathrm{CD}_{3} \mathrm{OD}\right)$

\begin{tabular}{|c|c|c|c|c|c|c|c|c|c|}
\hline $\mathrm{C}$ & 1 & $1 \mathrm{a}$ & $1 \mathbf{a}^{a)}$ & $\mathbf{2}^{b)}$ & $\mathbf{3}^{c)}$ & $4^{c)}$ & 5 & & $\mathbf{6}^{c)}$ \\
\hline 1 & 113.2 & 112.5 & 111.1 & 113.2 & 112.7 & 112.7 & 125.7 & & \\
\hline 2 & 157.3 & 157.2 & 157.1 & 157.2 & 157.2 & 157.3 & 157.2 & & \\
\hline 3 & 105.5 & 104.8 & 104.8 & 105.6 & 105.0 & 105.5 & 116.8 & & \\
\hline 4 & 159.7 & 159.9 & 160.3 & 159.6 & 160.1 & 159.7 & 129.7 & & \\
\hline 5 & 111.3 & 110.8 & 110.5 & 111.5 & 110.9 & 111.3 & 123.6 & & \\
\hline 6 & 130.8 & 130.8 & 130.2 & 130.8 & 130.7 & 130.8 & 132.1 & & \\
\hline 7 & 18.2 & 18.1 & 17.9 & 18.2 & 18.2 & 18.2 & 36.6 & & \\
\hline 8 & 120.1 & 120.2 & 119.5 & 120.0 & 120.1 & 120.1 & 174.7 & & \\
\hline $1^{\prime}$ & 103.6 & 103.1 & 103.3 & 103.6 & 103.1 & 103.2 & 103.0 & & \\
\hline $2^{\prime}$ & 74.9 & 74.9 & 74.8 & 73.4 & 74.8 & 74.8 & 75.0 & & \\
\hline $3^{\prime}$ & 77.9 & 78.1 & 78.4 & 78.9 & 77.9 & 77.9 & 78.2 & & \\
\hline $4^{\prime}$ & 71.4 & 71.3 & 71.0 & 69.9 & 71.8 & 71.6 & 71.4 & & \\
\hline $5^{\prime}$ & 75.8 & 78.3 & 78.8 & 75.5 & 75.8 & 75.6 & 78.1 & & \\
\hline $6^{\prime}$ & 64.5 & 62.5 & 62.2 & 64.3 & 65.0 & 64.6 & 62.6 & & \\
\hline $1^{\prime \prime}$ & 121.4 & & & $121.4^{\mathrm{a}}$ & 122.1 & 132.3 & & 1 & 132.4 \\
\hline $2^{\prime \prime}$ & 110.4 & & & $110.4^{\mathrm{b}}$ & 133.1 & 124.2 & & 2 & 123.6 \\
\hline $3^{\prime \prime}$ & 146.5 & & & $146.48^{\mathrm{c}}$ & 116.3 & 35.2 & & 3 & 32.8 \\
\hline $4^{\prime \prime}$ & 139.9 & & & $139.94^{\mathrm{d}}$ & 163.6 & 64.4 & & 4 & 75.1 \\
\hline $5^{\prime \prime}$ & 146.5 & & & $146.48^{\mathrm{c}}$ & 116.3 & 32.0 & & 5 & 29.4 \\
\hline $6^{\prime \prime}$ & 110.4 & & & $110.4^{\mathrm{b}}$ & 133.1 & 28.1 & & 6 & 27.3 \\
\hline $7^{\prime}$ & 168.4 & & & $168.27^{\mathrm{e}}$ & 168.2 & 43.4 & & 7 & 43.3 \\
\hline $8^{\prime \prime}$ & & & & & & 173.6 & & 8 & 174.0 \\
\hline$-\mathrm{OCH}_{3}$ & & & & & & & 52.5 & & 52.3 \\
\hline $1^{\prime \prime \prime}$ & & & & $121.8^{\mathrm{a}}$ & & & & & \\
\hline $2^{\prime \prime \prime}$ & & & & $110.5^{\mathrm{b}}$ & & & & & \\
\hline $3^{\prime \prime \prime}$ & & & & $146.53^{\mathrm{c}}$ & & & & & \\
\hline $4^{\prime \prime \prime}$ & & & & $139.86^{\mathrm{d}}$ & & & & & \\
\hline $5^{\prime \prime \prime}$ & & & & $146.53^{\mathrm{c}}$ & & & & & \\
\hline $6^{\prime \prime \prime}$ & & & & $110.5^{\mathrm{b}}$ & & & & & \\
\hline $7^{\prime \prime \prime}$ & & & & $168.29^{\mathrm{e}}$ & & & & & \\
\hline
\end{tabular}

a) Data for pyridine- $d_{5} . b$ ) Data with the same superscript may be interchanged. $c$ ) Data for $150 \mathrm{MHz}$.

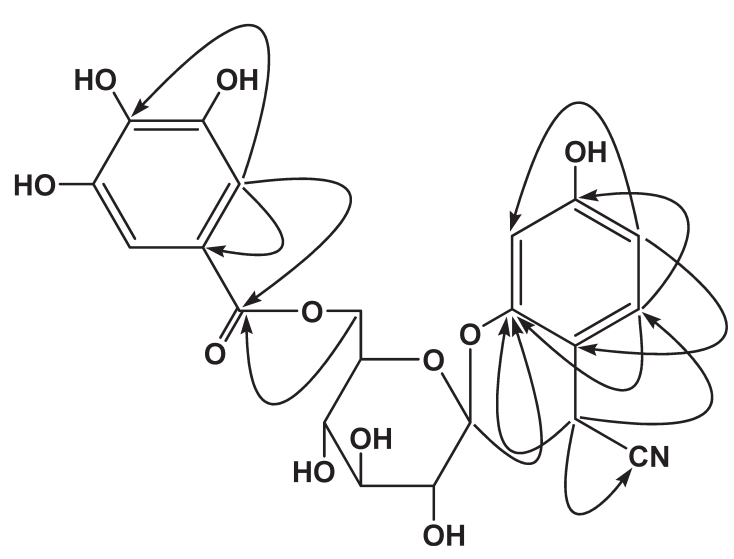

Fig. 2. Diagnostic HMBC Correlations for $\mathbf{1}$

assigned as those of $\beta$-glucopyranoside, ${ }^{2)}$ and the aglycone portion comprised a disubstituted benzene ring, and methylene and carbomethoxy carbons. The four aromatic protons were arranged in sequence and thus the structure of $\mathbf{5}$ was elucidated to be methyl 2-(2-hydroxyphenyl)acetate $\beta$-Dglucopyranoside, as shown in Fig. 1. From the 1-BuOH soluble fraction, a metal salt of 2-(2-hydroxyphenyl)acetic acid $\beta$-Dglucopyranoside was isolated, ${ }^{2)}$ and its metal free form was also expected as a new compound. However, the metal-free form was first isolated by Zhang et al. from the roots of Phyllanthus emblica ${ }^{10)}$ and its methyl ester (5) may be an artifact formed during the isolation procedures.

Compound 6, $[\alpha]_{\mathrm{D}}^{26}+3.5$, was isolated as an amorphous powder and its elemental composition was determined to be $\mathrm{C}_{9} \mathrm{H}_{14} \mathrm{O}_{6} \mathrm{~S}$ by HR-ESI-MS in a negative-ion mode. NMR spectra were similar to those of the acyl moiety of compound 4 with a signal of methoxy group. In Table 1 , the ${ }^{13} \mathrm{C}-\mathrm{NMR}$ data for 6 are listed in the double prime section for comparison with those of the acyl region of 4 . The 4-position was obviously shifted downfield $(\Delta \delta+10.7)$, and the 3 - and 5-positions upfield $(\Delta \delta-2.4$ and -2.6 , respectively). Therefore, the structure of $\mathbf{6}$ was expected to be the sulfuric acid ester of a methyl 2-(4-hydroxycyclohex-1-en-1-yl)acetate, as shown in Fig. 1. The absolute configuration at the 4-position was also expected to be $S$ from the co-occurring compounds in G. acuminatum, although the optical rotation sign was opposite to that of $(S)$ methyl 2-(4-hydroxycyclohex-1-en-1-yl)acetate in $\mathrm{MeOH}$, because sulfation had taken place on the hydroxy group, which is a crucial position for induction of optical activity.

\section{Experimental}

General Experimental Procedures Optical rotations were measured on a JASCO P-1030 digital polarimeter. IR and UV spectra were measured on Horiba FT-710 and JASCO V-520 UV/Vis spectrophotometers, respectively. ${ }^{1} \mathrm{H}$ and ${ }^{13} \mathrm{C}$-NMR spectra were taken on a JEOL JNM $\alpha-400$ at $400 \mathrm{MHz}$ and $100 \mathrm{MHz}$, respectively, or a Bruker Avance III at $600 \mathrm{MHz}$ and $150 \mathrm{MHz}$, respectively, with tetramethylsilane 
as an internal standard. HR-ESI-MS was performed with an Applied Biosystems QSTAR XL NanoSpray ${ }^{\mathrm{TM}}$ System.

Silica gel column chromatography (CC) was performed on silica gel 60 (E. Merck, Darmstadt, Germany), and for octadecyl silica (ODS) open CC Cosmosil $75 \mathrm{C}_{18}$-OPN (Nacalai Tesque, Kyoto, Japan) was used. The droplet counter-current chromatograph (DCCC) (DCC-300 supplemented with extra 200 columns, Tokyo Rikakikai, Tokyo, Japan) was equipped with 500 glass columns $(\Phi=2 \mathrm{~mm}, L=40 \mathrm{~cm})$, the lower and upper layers of a solvent mixture of $\mathrm{CHCl}_{3}-\mathrm{MeOH}-$ $\mathrm{H}_{2} \mathrm{O}-1-\mathrm{PrOH}(9: 12: 8: 2)$ being used as the stationary and mobile phases, respectively. Five-gram fractions were collected and numbered according to their order of elution with the mobile phase. HPLC (JASCO PU-980) was performed on an ODS column (Inertsil; GL Science, Tokyo, Japan; $\Phi=6 \mathrm{~mm}$, $L=250 \mathrm{~mm}, 1.6 \mathrm{~mL} / \mathrm{min})$, and the eluate was monitored with a UV detector (JASCO UV-975) at $254 \mathrm{~nm}$, and a refractive index monitor (JASCO RI-930).

Plant Material Leaves of $G$. acuminatum MüLleR Argoviensis (Euphorbiaceae) were collected in Okinawa, Japan, in August 1995, and a voucher specimen was deposited in the Herbarium of the Department of Pharmacognosy, Graduate School of Biomedical Sciences, Hiroshima University (95-GA-Okinawa-0801). The plant was identified by Dr. Takakazu Shinzato of Subtropical Field Science Center, Faculty of Agriculture, Unuversity of the Ryukyus.

Extraction and Isolation The air-dried leaves of $G$. acuminatum $(4.76 \mathrm{~kg})$ were extracted three times with $\mathrm{MeOH}$ $(30 \mathrm{~L})$. The $\mathrm{MeOH}$ extract was concentrated to $3.0 \mathrm{~L}$ and then $150 \mathrm{~mL}$ of $\mathrm{H}_{2} \mathrm{O}$ was added to make a $95 \%$ aqueous solution. This solution was washed with $3.0 \mathrm{~L}$ of $n$-hexane and then the methanolic layer was concentrated to a viscous gum $(823 \mathrm{~g})$. The gummy residue was suspended in $3.0 \mathrm{~L}$ of $\mathrm{H}_{2} \mathrm{O}$, and then extracted successively with $3.0 \mathrm{~L}$ each of EtOAc and 1-BuOH to afford $195 \mathrm{~g}$ and $288 \mathrm{~g}$ of EtOAc- and 1-BuOH-soluble fractions, respectively. The EtOAc-soluble fraction (194g) was subjected to silica gel $(900 \mathrm{~g})$ CC with stepwise increases in the acetone contents in toluene \{toluene $3 \mathrm{~L}$, toluene-acetone [9: 1 (3 L), $6: 1$ (3 L), $4: 1$ (3L), $3: 1$ (3L), 2: 1 (3L), $1: 1$ (3L) and $1: 2(3 \mathrm{~L}])$ and toluene-MeOH $[5: 1(3 \mathrm{~L}), 4: 1(3 \mathrm{~L})$, and $3: 1$ (3L)], 500-mL fractions being collected. The residue $(3.37 \mathrm{~g})$ in fractions $23-25$ was repeatedly subjected to silica gel $(60 \mathrm{~g}) \mathrm{CC}$ with stepwise increases in the acetone contents in $\mathrm{CHCl}_{3} \mathrm{CHCl}_{3} 500 \mathrm{~mL}, \mathrm{CHCl}_{3}$-actone [49:1 (500mL), $24: 1(500 \mathrm{~mL}), 47: 3(500 \mathrm{~mL}), 23: 2(500 \mathrm{~mL}), 9: 1(500 \mathrm{~mL})$, $4: 1(500 \mathrm{~mL})$, and $7: 3(500 \mathrm{~mL})]$ and $\mathrm{MeOH}(2 \mathrm{~L})\}, 5-\mathrm{g}$ fractions being collected. The residue $(747 \mathrm{mg})$ in fractions 66-82 was separated by ODS CC $(\Phi=2 \mathrm{~cm}, L=40 \mathrm{~cm})$ with $\mathrm{MeOH}-\mathrm{H}_{2} \mathrm{O}[1: 1(200 \mathrm{~mL}), 3: 2(200 \mathrm{~mL}), 7: 3(200 \mathrm{~mL}) 4: 1$ $(200 \mathrm{~mL})$, and 9:1 $(200 \mathrm{~mL})]$, and then $\mathrm{MeOH}(200 \mathrm{~mL}), 5-\mathrm{g}$ fractions being collected. The residue $(123 \mathrm{mg})$ in fractions 13-30 was finally purified by $\operatorname{HPLC}\left(\mathrm{MeOH}-\mathrm{H}_{2} \mathrm{O}, 7: 13\right)$ to give $38.1 \mathrm{mg}$ of 9 from the peak at $15.0 \mathrm{~min}$.

The residue $(35.7 \mathrm{~g})$ in fractions $26-29$ obtained on the first silica gel CC was repeatedly subjected to silica gel $(900 \mathrm{~g}) \mathrm{CC}$ with stepwise increases in the acetone contents in $\mathrm{CHCl}_{3}\left\{\mathrm{CHCl}_{3} 3 \mathrm{~L}, \mathrm{CHCl}_{3}\right.$-acetone [19:1 (3L), 9:1 (3L), $17: 3(3 \mathrm{~L}), 4: 1$ (3L), $7: 3(3 \mathrm{~L}), 3: 2(3 \mathrm{~L})$, and; $1: 1(3 \mathrm{~L})]$, and then $\mathrm{CHCl}_{3}-\mathrm{MeOH}[3: 1(3 \mathrm{~L}), 2: 1(3 \mathrm{~L})$, and $\left.1: 1(3 \mathrm{~L})]\right\}$ and $\mathrm{MeOH}(3 \mathrm{~L}), 500-\mathrm{mL}$ fractions being collected. The residue $(2.53 \mathrm{~g})$ in fractions $14-21$ was separated by ODS CC
$(\Phi=4.0 \mathrm{~cm}, L=22.5 \mathrm{~cm})$ with a linear gradient $\left[\mathrm{MeOH}-\mathrm{H}_{2} \mathrm{O}\right.$ $\left.(1: 1,1 \mathrm{~L}) \rightarrow \mathrm{MeOH}(1 \mathrm{~L}) \rightarrow \mathrm{CHCl}_{3}(1 \mathrm{~L})\right], 10$-g fractions being collected. The residue $(2.14 \mathrm{~g})$ was finally purified by HPLC $\left(\mathrm{MeOH}-\mathrm{H}_{2} \mathrm{O}, 1: 4\right)$ to yield $46.0 \mathrm{mg}$ of 7 and $31.3 \mathrm{mg}$ of 8 from the peaks at $6.0 \mathrm{~min}$ and $7.0 \mathrm{~min}$, respectively. The residue $(2.52 \mathrm{~g}$ out of $4.52 \mathrm{~g})$ in fractions 22-31 was separated by ODS $\mathrm{CC}(\Phi=4.0 \mathrm{~cm}, L=26.0 \mathrm{~cm})$ with linear gradient $\left[\mathrm{MeOH}-\mathrm{H}_{2} \mathrm{O}\right.$ $\left.(1: 1,1 \mathrm{~L}) \rightarrow \mathrm{MeOH}(1 \mathrm{~L}) \rightarrow \mathrm{CHCl}_{3}(1 \mathrm{~L})\right], 10$-g fractions being collected. The residue $(1.64 \mathrm{~g})$ in fractions $6-15$ was purified by silica gel CC $(\Phi=2.0 \mathrm{~cm}, L=23.0 \mathrm{~cm})$ with a linear gradient from $\mathrm{CHCl}_{3}(1 \mathrm{~L})$ to $\mathrm{CHCl}_{3}-\mathrm{MeOH}(9: 1,1 \mathrm{~L}), 15$-g fractions being collected, to give $606 \mathrm{mg}$ of 7 in fractions $4-27$.

The residue $(52.5 \mathrm{~g})$ in fractions $30-34$ obtained on the first silica gel CC was repeatedly subjected to silica gel $(750 \mathrm{~g}) \mathrm{CC}$ with stepwise increases in the $\mathrm{MeOH}$ content in $\mathrm{CHCl}_{3}\left\{\mathrm{CHCl}_{3}\right.$ $3 \mathrm{~L}, \mathrm{CHCl}_{3}-\mathrm{MeOH}[39: 1$ (3L), 19:1 (3L), 37:3 (3L), 9:1 (3L), 17:3, (3L), $4: 1$ (3L), $3: 1(3 \mathrm{~L}), 7: 3(3 \mathrm{~L})$, and $3: 2(3 \mathrm{~L})]\}$ and $\mathrm{CHCl}_{3}-\mathrm{MeOH}-\mathrm{H}_{2} \mathrm{O}(60: 40: 3,3.12 \mathrm{~L}), 500-\mathrm{mL}$ fractions being collected. The residue $(6.30 \mathrm{~g}$ out of $7.51 \mathrm{~g})$ in fractions $19-27$ was separated by ODS CC $(\Phi=2.0 \mathrm{~cm}, L=22.5 \mathrm{~cm})$ with $10 \%$ stepwise increases in the $\mathrm{MeOH}$ content in $\mathrm{H}_{2} \mathrm{O}$ from $10 \% \mathrm{MeOH}$ to $100 \% \mathrm{MeOH}(400 \mathrm{~mL}$ each), 10 -g fractions being collected. The residue $(220 \mathrm{mg})$ in fractions $125-138$ was separated by silica gel $\mathrm{CC}(40 \mathrm{~g})$ with stepwise increases in the $\mathrm{MeOH}$ contents in $\mathrm{CHCl}_{3}\left\{\mathrm{CHCl}_{3} 200 \mathrm{~mL}, \mathrm{CHCl}_{3}-\mathrm{MeOH}\right.$ [19:1 (200mL), 9:1 (200mL), 17:3, (200mL), 4:1 (200mL), $3: 1(200 \mathrm{~mL})$, and $7: 3(200 \mathrm{~mL})]\}, 10$-g fractions being collected. The residue $(32.5 \mathrm{mg})$ in fractions $111-131$ was purified by HPLC $\left[\mathrm{MeOH}-\mathrm{H}_{2} \mathrm{O}(1: 1), 2.0 \mathrm{~mL} / \mathrm{min}\right]$ to give $8.8 \mathrm{mg}$ of $\mathbf{5}$ from the peak at $12.0 \mathrm{~min}$. The residue $(42.3 \mathrm{mg})$ in fractions $132-143$ was purified by HPLC $\left[\mathrm{MeOH}-\mathrm{H}_{2} \mathrm{O}(1: 1), 2.0 \mathrm{~mL} /\right.$ $\mathrm{min}$ ] to give $4.9 \mathrm{mg}$ of 4 and $16.2 \mathrm{mg}$ of 3 from the peaks at $12.2 \mathrm{~min}$ and $13.4 \mathrm{~min}$, respectively. The residue $(19.9 \mathrm{mg})$ in fractions $144-159$ obtained on the second silica gel CC was separated by HPLC $\left[\mathrm{MeOH}-\mathrm{H}_{2} \mathrm{O}(9: 11), 2.0 \mathrm{~mL} / \mathrm{min}\right]$ to give $2.7 \mathrm{mg}$ of $\mathbf{1 1}$ from the peak at $35.4 \mathrm{~min}$.

The residue $(4.66 \mathrm{~g}$ out of $6.78 \mathrm{~g}$ ) in fractions $28-33 \mathrm{ob}-$ tained on the second silica gel CC was separated by ODS CC $(\Phi=4.0 \mathrm{~cm}, L=24.5 \mathrm{~cm})$ with a linear gradient $\left[\mathrm{MeOH}-\mathrm{H}_{2} \mathrm{O}\right.$ $\left.(1: 1,1 \mathrm{~L}) \rightarrow \mathrm{MeOH}(1 \mathrm{~L}) \rightarrow \mathrm{CHCl}_{3}(1 \mathrm{~L})\right], 10$-g fractions being collected. The residue $(200 \mathrm{mg})$ in fractions $27-48$ was purified by silica gel $\mathrm{CC}(35 \mathrm{~g})$ with stepwise increases in the $\mathrm{MeOH}$ content in $\mathrm{CHCl}_{3}\left\{\mathrm{CHCl}_{3} 200 \mathrm{~mL}, \mathrm{CHCl}_{3}-\mathrm{MeOH}\right.$ [19:1 (200 mL), 9:1 (200 mL), 17:3, (200mL), $4: 1(200 \mathrm{~mL})$, $3: 1(200 \mathrm{~mL})$, and $7: 3(200 \mathrm{~mL})]\}, 10-\mathrm{g}$ fractions being collected, to give $5306 \mathrm{mg}$ of 6 in fractions $177-200$. The residue $(387 \mathrm{mg})$ in fractions $83-99$ was subjected to DCCC to give $114 \mathrm{mg}$ of $\mathbf{1 0}$ in fractions $13-17$ and $210 \mathrm{mg}$ of $\mathbf{1}$ in fractions $18-24$. The residue $(5.90 \mathrm{~g})$ in fractions $34-42$ obtained on the second silica gel CC was purified by ODS CC $(\Phi=4.0 \mathrm{~cm}$, $L=24.5 \mathrm{~cm})$ with a linear gradient $\left[\mathrm{MeOH}-\mathrm{H}_{2} \mathrm{O} \quad(1: 1\right.$, $\left.1 \mathrm{~L}) \rightarrow \mathrm{MeOH}(1 \mathrm{~L}) \rightarrow \mathrm{CHCl}_{3}(1 \mathrm{~L})\right], 10$-g fractions being collected. The residue $(40.3 \mathrm{mg}$ out of $130 \mathrm{mg})$ in fractions $141-150$ was purified by HPLC $\left(\mathrm{MeOH}-\mathrm{H}_{2} \mathrm{O}, 1: 1\right)$ to give $24.3 \mathrm{mg}$ of 2 from the peak at $34.0 \mathrm{~min}$.

Compound 1: Off-white amorphous powder; $[\alpha]_{\mathrm{D}}^{25}-45.1$ $(c=0.49, \mathrm{MeOH})$; IR $v_{\max }($ film $) \mathrm{cm}^{-1}: 3323,2945,2260,1699$, 1614, 1511, 1239, 1073, 1038; UV $\lambda_{\text {max }}(\mathrm{MeOH}) \mathrm{nm}(\log \varepsilon)$ : 278 (4.05), 216 (4.37); ${ }^{1} \mathrm{H}-\mathrm{NMR}$ (400 MHz; CD $\left.\mathrm{OD}\right) \delta: 7.12$ $(1 \mathrm{H}, \mathrm{d}, J=8 \mathrm{~Hz}, \mathrm{H}-6), 7.08\left(2 \mathrm{H}, \mathrm{s}, \mathrm{H}-2^{\prime \prime}\right.$ and $\left.6^{\prime \prime}\right), 6.69(1 \mathrm{H}$, d, $J=2 \mathrm{~Hz}, \mathrm{H}-3), 6.51(1 \mathrm{H}, \mathrm{dd}, J=8,2 \mathrm{~Hz}, \mathrm{H}-5), 4.87(1 \mathrm{H}, \mathrm{d}$, 
$\left.J=7 \mathrm{~Hz}, \mathrm{H}-1^{\prime}\right), 4.58\left(1 \mathrm{H}, \mathrm{dd}, J=12,2 \mathrm{~Hz}, \mathrm{H}-6^{\prime} \mathrm{a}\right), 4.48(1 \mathrm{H}$, dd, $\left.J=12,5 \mathrm{~Hz}, \mathrm{H}-6^{\prime} \mathrm{b}\right), 3.78(1 \mathrm{H}, \mathrm{d}, J=11 \mathrm{~Hz}, \mathrm{H}-7 \mathrm{a}), 3.77(1 \mathrm{H}$, d, $J=11 \mathrm{~Hz}, \mathrm{H}-7 \mathrm{~b}), 3.54-3.51\left(4 \mathrm{H}, \mathrm{m}, \mathrm{H}-2^{\prime}, 3^{\prime}, 4^{\prime}\right.$, and $\left.5^{\prime}\right)$; ${ }^{13} \mathrm{C}-\mathrm{NMR}\left(100 \mathrm{MHz}, \mathrm{CD}_{3} \mathrm{OD}\right)$ : Table 1; HR-ESI-MS (positiveion mode) $m / z$ : $486.1000[\mathrm{M}+\mathrm{Na}]^{+}\left(\mathrm{Calcd}\right.$ for $\mathrm{C}_{21} \mathrm{H}_{21} \mathrm{NO}_{11} \mathrm{Na}$ : 486.1007).

Compound 2: Off-white amorphous powder; $[\alpha]_{\mathrm{D}}^{25}-5.1$ $(c=1.62, \mathrm{MeOH})$; IR $v_{\max }$ (film) $\mathrm{cm}^{-1}: 3363,2925,2260,1700$, 1614, 1452, 1230, 1076, 1036; UV $\lambda_{\max }(\mathrm{MeOH}) \mathrm{nm}(\log \varepsilon): 272$ (4.17), 223 (4.29); ${ }^{1} \mathrm{H}-\mathrm{NMR}$ (400 MHz; CD $\left.\mathrm{OD}\right) \delta: 7.14(1 \mathrm{H}, \mathrm{d}$, $J=8 \mathrm{~Hz}, \mathrm{H}-6), 7.17$ (2H, s, H-2" and 6", or H-2"' and $\left.6^{\prime \prime \prime}\right), 7.10$ $\left(2 \mathrm{H}, \mathrm{s}, \mathrm{H}-2^{\prime \prime \prime}\right.$ and $6^{\prime \prime \prime}$, or $\mathrm{H}-2^{\prime \prime}$ and $\left.6^{\prime \prime}\right), 6.74(1 \mathrm{H}, \mathrm{d}, J=2 \mathrm{~Hz}$, $\mathrm{H}-3), 6.53(1 \mathrm{H}, \mathrm{dd}, J=8,2 \mathrm{~Hz}, \mathrm{H}-5), 5.26(1 \mathrm{H}, \mathrm{dd}, J=9,9 \mathrm{~Hz}$, $\left.\mathrm{H}-3^{\prime}\right), 5.02\left(1 \mathrm{H}, \mathrm{d}, J=8 \mathrm{~Hz}, \mathrm{H}-1^{\prime}\right), 4.60(1 \mathrm{H}, \mathrm{dd}, J=12,2 \mathrm{~Hz}$, H-6'a), 4.50 (1H, dd, $\left.J=12,5 \mathrm{~Hz}, \mathrm{H}-6^{\prime} \mathrm{b}\right), 3.84-3.78$ (4H, m, $\mathrm{H}-2^{\prime}, 4^{\prime}$, and $\left.5^{\prime}\right), 3.77(1 \mathrm{H}, \mathrm{d}, J=11 \mathrm{~Hz}, \mathrm{H}-7 \mathrm{a}), 3.76(1 \mathrm{H}, \mathrm{d}$, $J=11 \mathrm{~Hz}, \mathrm{H}-7 \mathrm{~b}) ;{ }^{13} \mathrm{C}-\mathrm{NMR}\left(100 \mathrm{MHz}, \mathrm{CD}_{3} \mathrm{OD}\right)$ : Table 1; HRESI-MS (positive-ion mode) $\mathrm{m} / \mathrm{z}: 638.1105[\mathrm{M}+\mathrm{Na}]^{+}$(Calcd for $\mathrm{C}_{28} \mathrm{H}_{25} \mathrm{NO}_{15} \mathrm{Na}$ : 638.1116).

Compound 3: Colorless amorphous powder; $[\alpha]_{\mathrm{D}}^{26}-42.9$ $(c=1.08, \mathrm{MeOH})$; IR $v_{\max }$ (film) $\mathrm{cm}^{-1}: 3332,2959,2267,1726$, $1605,1511,1234,1071,1013 ; \mathrm{UV} \lambda_{\max }(\mathrm{MeOH}) \mathrm{nm}(\log \varepsilon): 259$ (4.13), 215 (4.12); ${ }^{1} \mathrm{H}-\mathrm{NMR}$ (600 MHz; CD 3 OD) $\delta: 7.90(2 \mathrm{H}$, $\mathrm{d}, J=9 \mathrm{~Hz}, \mathrm{H}-2^{\prime \prime}$ and $\left.6^{\prime \prime}\right), 7.13(1 \mathrm{H}, \mathrm{d}, J=8 \mathrm{~Hz}, \mathrm{H}-6), 6.82(2 \mathrm{H}$, $\mathrm{d}, J=9 \mathrm{~Hz}, \mathrm{H}-2^{\prime \prime}$ and $\left.5^{\prime \prime}\right), 6.72(1 \mathrm{H}, \mathrm{d}, J=2 \mathrm{~Hz}, \mathrm{H}-3), 6.51(1 \mathrm{H}$, dd, $J=8,2 \mathrm{~Hz}, \mathrm{H}-5), 4.91\left(1 \mathrm{H}, \mathrm{d}, J=7 \mathrm{~Hz}, \mathrm{H}-1^{\prime}\right), 4.69(1 \mathrm{H}, \mathrm{dd}$, $\left.J=12,2 \mathrm{~Hz}, \mathrm{H}-6^{\prime} \mathrm{a}\right), 4.31$ (1H, dd, $\left.J=12,7 \mathrm{~Hz}, \mathrm{H}-6^{\prime} \mathrm{b}\right), 3.80(1 \mathrm{H}$, d, $J=18 \mathrm{~Hz}, \mathrm{H}-7 \mathrm{a}), 3.75(1 \mathrm{H}, \mathrm{d}, J=18 \mathrm{~Hz}, \mathrm{H}-7 \mathrm{~b}), 3.74(1 \mathrm{H}, \mathrm{m}$, $\left.\mathrm{H}-5^{\prime}\right), 3.54\left(1 \mathrm{H}, \mathrm{dd}, J=9,7 \mathrm{~Hz}, \mathrm{H}-2^{\prime}\right), 3.51(1 \mathrm{H}, \mathrm{dd}, J=9,9 \mathrm{~Hz}$, $\left.\mathrm{H}-3^{\prime}\right), 3.46\left(1 \mathrm{H}, \mathrm{dd}, J=9,9 \mathrm{~Hz}, \mathrm{H}-4^{\prime}\right) ;{ }^{13} \mathrm{C}-\mathrm{NMR}(150 \mathrm{MHz}$, $\mathrm{CD}_{3} \mathrm{OD}$ ): Table 1; HR-ESI-MS (positive-ion mode) $\mathrm{m} / \mathrm{z}$ : 454.1108 [M+Na] ${ }^{+}$(Calcd for $\mathrm{C}_{21} \mathrm{H}_{21} \mathrm{NO}_{9} \mathrm{Na}$ : 454.1109).

Compound 4: Colorless amorphous powder; $[\alpha]_{\mathrm{D}}^{26}-61.8$ $(c=0.33, \mathrm{MeOH})$; IR $v_{\max }($ film $) \mathrm{cm}^{-1}: 3363,2927,2256,1726$, $1605,1587,1517,1171,1073,1020 ; \mathrm{UV} \lambda_{\max }(\mathrm{MeOH}) \mathrm{nm}$ ( $\log \varepsilon): 268$ (4.90), 209 (4.30); ${ }^{1} \mathrm{H}-\mathrm{NMR}\left(600 \mathrm{MHz} ; \mathrm{CD}_{3} \mathrm{OD}\right) \delta$ : $7.15(1 \mathrm{H}, \mathrm{d}, J=8 \mathrm{~Hz}, \mathrm{H}-6), 6.64(1 \mathrm{H}, \mathrm{d}, J=2 \mathrm{~Hz}, \mathrm{H}-3), 6.51(1 \mathrm{H}$, $\mathrm{dd}, J=8,2 \mathrm{~Hz}, \mathrm{H}-5), 5.45$ (1H, br s, H-2"), $4.81(1 \mathrm{H}, \mathrm{d}, J=8 \mathrm{~Hz}$, H-1'), 4.44 (1H, dd, $\left.J=12,2 \mathrm{~Hz}, \mathrm{H}-6^{\prime} \mathrm{a}\right), 4.25$ (1H, dd, $J=12$, $\left.6 \mathrm{~Hz}, \mathrm{H}-6^{\prime} \mathrm{b}\right), 3.80$ (1H, m, H-4"), 3.77 (2H, m, H -7$), 3.61(1 \mathrm{H}$, ddd, $\left.J=9,6,2 \mathrm{~Hz}, \mathrm{H}-5^{\prime}\right), 3.49$ (1H, dd, $\left.J=9,9 \mathrm{~Hz}, \mathrm{H}-2^{\prime}\right), 3.46$ $\left(1 \mathrm{H}, \mathrm{dd}, J=9,9 \mathrm{~Hz}, \mathrm{H}-3^{\prime}\right), 3.38\left(1 \mathrm{H}, \mathrm{dd}, J=9,9 \mathrm{~Hz}, \mathrm{H}-4^{\prime}\right), 3.02$ (2H, s, H $\left.7^{\prime \prime}\right), 2.28\left(1 \mathrm{H}\right.$, brd, $\left.J=17 \mathrm{~Hz}, \mathrm{H}-3^{\prime \prime} \mathrm{a}\right), 2.10$ (2H, m, $\left.\mathrm{H}_{2}-6^{\prime \prime}\right), 1.94$ (1H, brd, $\left.J=17 \mathrm{~Hz}, \mathrm{H}-3^{\prime \prime} \mathrm{b}\right), 1.80$ (1H, m, H-5"a), 1.55 (1H, m, H-5"b); ${ }^{13} \mathrm{C}-\mathrm{NMR}$ (150 MHz, CD $\left.3 \mathrm{OD}\right)$ : Table 1; HR-ESI-MS (positive-ion mode) $\mathrm{m} / \mathrm{z}: 472.1576[\mathrm{M}+\mathrm{Na}]^{+}$ (Calcd for $\mathrm{C}_{22} \mathrm{H}_{27} \mathrm{NO}_{9} \mathrm{Na}$ : 472.1578).

Compound 5: Colorless amorphous powder; $[\alpha]_{\mathrm{D}}^{26}-38.0$ $(c=0.59, \mathrm{MeOH})$; IR $v_{\max }($ film $) \mathrm{cm}^{-1}: 3367,2938,2878,1726$, 1587, 1528, 1227, 1075, 1042, 1014; UV $\lambda_{\max }(\mathrm{MeOH}) \mathrm{nm}$ ( $\log \varepsilon$ ): 266 (2.96), 214 (3.83); ${ }^{1} \mathrm{H}-\mathrm{NMR}\left(600 \mathrm{MHz} ; \mathrm{CD}_{3} \mathrm{OD}\right) \delta$ : 7.24 (1H, ddd, $J=7,1,1 \mathrm{~Hz}, \mathrm{H}-4), 7.20-7.18$ (2H, m, H-3 and 6), $6.99(1 \mathrm{H}, \mathrm{ddd}, J=7,1,1 \mathrm{~Hz}, \mathrm{H}-5), 4.88(1 \mathrm{H}, \mathrm{d}, J=8 \mathrm{~Hz}$, H-1'), 3.88 (1H, dd, $\left.J=12,2 \mathrm{~Hz}, \mathrm{H}-6^{\prime} \mathrm{a}\right), 3.69$ (1H, dd, $J=12$, $\left.5 \mathrm{~Hz}, \mathrm{H}-6^{\prime} \mathrm{b}\right), 3.46-3.38$ (4H, m, H-2', 3', 4', and 5'), $3.67(3 \mathrm{H}$, $\left.\mathrm{s},-\mathrm{OCH}_{3}\right) ;{ }^{13} \mathrm{C}-\mathrm{NMR}\left(150 \mathrm{MHz}, \mathrm{CD}_{3} \mathrm{OD}\right)$ : Table 1; HR-ESIMS (positive-ion mode) $\mathrm{m} / \mathrm{z}$ : $351.1055[\mathrm{M}+\mathrm{Na}]^{+}$(Calcd for $\mathrm{C}_{15} \mathrm{H}_{20} \mathrm{O}_{8} \mathrm{Na}$ : 351.1050).

Compound 6: Colorless amorphous powder; $[\alpha]_{\mathrm{D}}^{26}+3.5$ $(c=1.36, \mathrm{MeOH})$; IR $v_{\max }$ (film) $\mathrm{cm}^{-1}: 3423,1731,1718,1218$, 1069; ${ }^{1} \mathrm{H}-\mathrm{NMR}\left(600 \mathrm{MHz}\right.$; $\left.\mathrm{CD}_{3} \mathrm{OD}\right) \delta: 5.45$ (1H, brs, H-2), 3.80
$(1 \mathrm{H}, \mathrm{m}, \mathrm{H}-4), 3.66\left(3 \mathrm{H}, \mathrm{s},-\mathrm{OCH}_{3}\right), 3.00\left(2 \mathrm{H}, \mathrm{s}, \mathrm{H}_{2}-7\right), 2.48$ (1H, brd, $J=17 \mathrm{~Hz}, \mathrm{H}-3 \mathrm{a}), 2.24$ (1H, brd, $J=17 \mathrm{~Hz}, \mathrm{H}-3 \mathrm{~b}), 2.19$ (2H, m, H-6a), 2.14 (1H, m, H-6b), 2.01 (1H, dddd, $J=9,6,3$, $1 \mathrm{~Hz}, \mathrm{H}-5 \mathrm{a}), 1.85$ (1H, m, H-5b); ${ }^{13} \mathrm{C}-\mathrm{NMR}\left(150 \mathrm{MHz}, \mathrm{CD}_{3} \mathrm{OD}\right)$ : Table 1; HR-ESI-MS (negative-ion mode) $\mathrm{m} / \mathrm{z}: 249.0434$ $[\mathrm{M}-\mathrm{H}]^{-}$(Calcd for $\mathrm{C}_{9} \mathrm{H}_{13} \mathrm{O}_{6} \mathrm{~S}: 249.0427$ ).

Mild Alkaline Hydrolysis of 1 Compound 1 (16 mg) was treated in $1 \mathrm{~mL}$ of $0.1 \mathrm{M} \mathrm{CH} \mathrm{CH}_{3} \mathrm{ONa}$ in $\mathrm{MeOH}$ for $3 \mathrm{~h}$ at $35^{\circ} \mathrm{C}$. The reaction mixture was diluted with $4 \mathrm{~mL}$ of $\mathrm{H}_{2} \mathrm{O}$ and then neutralized with Amberlite IR-120B $\left(\mathrm{H}^{+}\right)$. The aqueous layer was extracted with $\mathrm{CHCl}_{3}(4 \mathrm{~mL})$ and then evaporated to dryness. The residue was dissolved in $\mathrm{MeOH}$ and the precipitate formed was removed by filtration to leave $10 \mathrm{mg}$ of $\mathbf{1 a}(=\mathbf{1 2})$. An expected compound, methyl gallate, was not present in the $\mathrm{CHCl}_{3}$ layer. Probably it was decomposed in the basic media.

The NMR spectroscopic data for 1a for pyridine- $d_{5}$ were identical with those of ehretioside B (12), ${ }^{7)}$ and those for $\mathrm{CD}_{3} \mathrm{OD}$ with those of $\mathbf{1 2}$ isolated from $S$. adoxoides $^{8)}$ (Table 1).

Sugar Analysis About $1.0 \mathrm{mg}$ aliquots of compounds 1-5 were hydrolyzed with $1 \mathrm{M} \mathrm{HCl}(0.1 \mathrm{~mL})$ at $90^{\circ} \mathrm{C}$ for $2 \mathrm{~h}$. The reaction mixtures were then each washed with an equal amount of EtOAc and the aqueous layers were analyzed by HPLC, which gave a peak for D-glucose at $15.2 \mathrm{~min}$ with positive optical rotation signs. [Optical rotation detector: JASCO OR2090Plus, column: Shodex Asahipak NH2P-50; $\Phi=4.5 \mathrm{~mm}$, $L=25 \mathrm{~cm}$, solvent: $\left.\mathrm{CH}_{3} \mathrm{CN}-\mathrm{H}_{2} \mathrm{O}(4: 1), 1 \mathrm{~mL} / \mathrm{min}\right]$. Peaks were identified by co-chromatography with authentic D-glucose.

Acknowledgments The authors are grateful for access to the superconducting NMR instrument (JEOL JNM $\alpha-400)$ and an Applied Biosystem QSTAR XL system ESI (Nano Spray)MS at the Analysis Center of Life Science of the Graduate School of Biomedical Sciences, Hiroshima University. This work was supported in part by Grants-in-Aid from the Ministry of Education, Culture, Sports, Science and Technology of Japan (Nos. 22590006, 23590130, and 25860078), the Japan Society for the Promotion of Science, and the Ministry of Health, Labour and Welfare. Thanks are also due to the Research Foundation for Pharmaceutical Sciences and the Takeda Science Foundation for the financial support.

Conflict of Interest The authors declare no conflict of interest.

\section{References}

1) Otsuka H., Kotani K., Bando M., Kido M., Takeda Y., Chem. Pharm. Bull., 46, 1180-1181 (1998).

2) Otsuka H., Takeda Y., Hirata E., Shinzato T., Bando M., Chem. Pharm. Bull., 52, 591-596 (2004).

3) Kawakita A., Takimura A., Terachi T., Sota T., Kato M., Evolution, 58, 2201-2214 (2004).

4) Elo Manga S. S., Messanga B. B., Sondengam B. L., Fitoterapia, 72, 706-708 (2001)

5) Valdes L. J. III, J. Nat. Prod., 49, 171 (1986).

6) Eldahshan O. A., Curr. Res. J. Biol. Sci., 3, 52-55 (2011).

7) Kubo I., Matsumoto A., Chem. Pharm. Bull., 33, 3817-3820 (1985).

8) Simpol L. R., Otsuka H., Ohtani K., Kasai R., Yamasaki K., Phytochemistry, 36, 91-95 (1994).

9) Su Y.-F., Zhang Z.-X., Guo C.-Y., Guo D.Y., J. Asian Nat. Prod. Res., 2, 171-174 (2005).

10) Zhang Y.-J., Tanaka T., Iwamoto Y., Yang C.-R., Kouno I., J. Nat. Prod., 64, 870-873 (2001). 